\title{
CHARACTERIZATION OF EXOPOLYSACCHARIDES PRODUCED BY RHIZOBIA SPECIES
}

\author{
Tereza Cristina Luque Castellane ${ }^{(1)}$, Alda Maria Machado Bueno Otoboni ${ }^{(2)}$ and Eliana \\ Gertrudes de Macedo $\operatorname{Lemos}^{(1)^{*}}$
}

(1) Universidade Estadual Paulista, Faculdade de Ciências Agrárias e Veterinárias, Departamento de Tecnologia, Laboratório de Bioquímica de Microrganismos e Plantas, Jaboticabal, São Paulo, Brasil.

(2) Faculdade de Tecnologia de Marilia, Marília, São Paulo, Brasil.

* Corresponding author.

E-mail: egerle@fcav.unesp.br

\begin{abstract}
Increasing attention has been given, over the past decades, to the production of exopolysaccharides (EPS) from rhizobia, due to their various biotechnological applications. Overall characterization of biopolymers involves evaluation of their chemical, physical, and biological properties; this evaluation is a key factor in understanding their behavior in different environments, which enables researchers to foresee their potential applications. Our focus was to study the EPS produced by Mesorhizobium huakuii LMG14107, M. loti LMG6125, M. plurifarium LMG11892, Rhizobium giardini bv. giardini $\mathrm{H152}^{\mathrm{T}}, \boldsymbol{R}$. mongolense LMG19141, and Sinorhizobium (= Ensifer) kostiense LMG19227 in a RDM medium with glycerol as a carbon source. These biopolymers were isolated and characterized by reversed-phase high-performance liquid chromatography (RP-HPLC), Fourier transform infrared (FTIR), and nuclear magnetic resonance (NMR) spectroscopies. Maximum exopolysaccharide production was $3.10,2.72$, and $2.50 \mathrm{~g} \mathrm{~L}^{-1}$ for the strains LMG6125, LMG19227, and LMG19141, respectively. The purified EPS revealed prominent functional reactive groups, such as hydroxyl and carboxylic, which correspond to a typical heteropolysaccharide. The EPS are composed primarily of galactose and glucose. Minor components found were rhamnose, glucuronic acid, and galacturonic acid. Indeed, from the results of techniques applied in this study, it can be noted that the EPS are species-specific heteropolysaccharide polymers composed of common sugars that are substituted by non-carbohydrate moieties. In addition, analysis of these results indicates that rhizobial EPS can be classified into five groups based on ester type, as determined
\end{abstract}


from the ${ }^{13} \mathrm{C}$ NMR spectra. Knowledge of the EPS composition now facilitates further investigations relating polysaccharide structure and dynamics to rheological properties.

Keywords: acidic exopolysaccharide, Fourier transform infrared, microbial heteropolysaccharides, Rhizobium, Sinorhizobium.

\title{
RESUMO: CARACTERIZAÇÃO DE EXOPOLISSACARÍDEOS PRODUZIDOS POR ESPÉCIES DE RIZÓBIOS
}

\begin{abstract}
Atenção crescente tem sido dada, nas últimas décadas, à produção de exopolissacarideos (EPS) a partir de rizóbio, em razão das suas diversas aplicações biotecnológicas. Uma ampla caracterização de biopolímeros envolve a avaliação de suas propriedades químicas, físicas e biológicas, sendo um fator-chave para entender o seu comportamento em diferentes ambientes, o que permite prever suas potenciais aplicações. Objetivou-se estudar os EPS produzidos pelas espécies de Mesorhizobium huakuii LMG14107, M. loti LMG6125, M. plurifarium LMG11892, Rhizobium giardini bv. giardini H152T $R$. mongolense LMG19141 e Sinorhizobium (= Ensifer) kostiense LMG19227 em meio RDM com glicerol como fonte de carbono. Esses biopolimeros foram isolados e caracterizados por Cromatografia Liquida de Alta Eficiência de Fase Reversa (RP-HPLC), Ressonância Magnética Nuclear (NMR) e Infravermelho por Transformada de Fourier (FTIR). A máxima produção de exopolissacarídeo foi de 3,10; 2,72 e 2,50 g $L^{-1}$ para as estirpes LMG6125, LMG19227 e LMG19141, respectivamente. Os EPS purificados revelaram proeminentes grupos funcionais, como hidroxilo e carboxílico, o que corresponde a um heteropolissacarídeo. Os EPS são compostos principalmente por galactose e glucose. Outros componentes foram encontrados em menor concentração ramnose, ácido glucurônico e ácido galacturônico. Com base nas técnicas utilizadas, verificou-se que os EPS são heteropolissacarídeos específicos para cada espécie, compostos de açúcares comuns que são substituídos com porções de não hidratos de carbono. Os EPS rizobianos podem ser classificados em cinco grupos com base no tipo éster, como determinado a partir dos espectros de RMN de ${ }^{13} \mathrm{C}$. O conhecimento da composição EPS agora facilita novas investigações como a estrutura e propriedades reológicas dos polissacarídeos.
\end{abstract}

Palavras-chave: exopolissacarídeo ácido, infravermelho com transformada de Fourier, heteropolissacarídeos microbianos, Rhizobium, Sinorhizobium.

\section{INTRODUCTION}

Soil bacteria collectively termed rhizobia are taxonomically, metabolically, and genetically diverse (Marcondes et al., 2014). There are more than 98 species belonging to 14 genera of $\alpha-$ and B- proteobacteria which have been described as rhizobia (Berrada and Fikri-Benbrahim, 2014). Most bacteria known as legume symbionts belong to the genera of the a- Proteobacteria class, listed as Rhizobium, Mesorhizobium, Bradyrhizobium, Azorhizobium, and Ensifer (formerly Sinorhizobium) (Berrada and Fikri-Benbrahim, 2014; Carareto et al., 2014; Marcondes et al., 2014). Exopolysaccharides (EPS) play important roles in various biological mechanisms, such as adhesion and infection, especially important for the initial stages of the symbiotic invasion that leads to the formation of indeterminate-type nodules on legume plants (Fabaceae family) such as pea and alfalfa (Skorupska et al., 2006). Exopolysaccharides are long-chain polysaccharides consisting of branched, repeating units of sugars or sugar derivatives and non-carbohydrate components (Whitfield, 1988; Sutherland, 2001; Bomfeti et al., 2011).
Exopolysaccharide has rapidly emerged as a new and industrially important source of polymeric materials, which are gradually becoming economically competitive (Singh and Saini, 2012). Interest in the exploitation of microorganisms for production of valuable polysaccharides has greatly increased in recent years, since these biopolymers produced by a variety of microorganisms are chemically well defined and have attracted worldwide attention due to their novel and unique physical properties as bioadhesives, bioflocculants, biosorbents, gelling agents, probiotics, stabilizers, and thickeners, making them suitable for numerous commercial applications in the bionanotechnology, food, pharmaceutical, cosmetics, petroleum, civil construction, and environmental sectors. They have the advantages of being ecofriendly, non-toxic, and biodegradable (Freitas et al., 2011; Donot et al., 2012).

Rhizobia is an important group with several advantages over other groups - they are easy to cultivate, and these strains have proven to be safe as non-pathogenic species over many years. Rhizobial EPS also have a wide range of useful technological characteristics and potential for industrial application on the production of gums, and polysaccharidic 
compounds are important in soil aggregation (Bomfeti et al., 2011). Rhizobial EPS can increase the adhesion of soil particles to plant roots and the mechanical stability of rhizospherical soils, and can also increase the level of water retention in this environment (Bomfeti et al., 2011; Donot et al., 2012).

Until now, the common EPS produced by microorganisms used in the market include only one type of rhizobial EPS that has been studied in more detail, namely succinoglycan (also called EPS I), extracted from Sinorhizobium meliloti (Sutherland, 2001). This is composed of a B-1,3, B-1,4, and B-1,6 linked octasaccharide subunit containing galactose at the reducing end and glucose residues in a ratio of 1:7. Also, the repeating unit carries one to two succinyl groups located at the C- 6 position of the seventh sugar residue, and a pyruvyl group linked to the eighth sugar residue through a 4, 6-ketal linkage (Chouly et al., 1995; Choi et al., 2012). Sinorhizobial polymers represent only a small fraction of the current polymer market (Donot et al., 2012). However, at this time, there is little physicochemical and industrial information available.

The structures of the EPS repeating units of several rhizobial strains belonging to different genera were established, and among them are the structures for $R$. leguminosarum, S. meliloti, B. japonicum, B. elkanii, S. fredii NGR234, $R$. tropici CIAT899, and $R$. tropici SEMIA 4080. The galactoglucopolysaccharides obtained from Achromobacter spp., Agrobacterium radiobacter, Pseudomonas marginalis, Rhizobium spp., Rhizobium sullea, and Zooglea spp. have also been described (Donot et al., 2012; Gharzouli et al., 2013). In addition to sugar composition, types of linkages and non-sugar modification have already been described (Sutherland, 2001; Castellane and Lemos, 2007; Janczarek and Skorupska, 2011; Silvi et al., 2013; Castellane et al., 2014, 2015). On the basis of monosaccharide composition in their backbone, bacterial EPS have been classified into homopolysaccharides and heteropolysaccharides (Donot et al., 2012). They are generally constituted by monosaccharides and non-carbohydrate substituents (such as acetate, pyruvate, succinate, and phosphate). Components most commonly found in EPS are monosaccharides such as pentoses (D-arabinose, and D-xylose), hexoses (D-glucose, D-galactose, D-mannose, D-allose), desoxyhexoses (L-rhamnose, L-fucose), amino sugars (D-glucosamine and D-galactosamine), or uronic acids (D-glucuronic acids and D-galacturonic acids). The linkages most commonly found between monosaccharides are $1,4-\beta$ - or $1,3-\beta$-linkages in the backbones characterized by strong rigidity, and 1,2- $\alpha$ - or 1,6-a-linkages in the more flexible ones. The physical properties of polysaccharides are deeply influenced by the way the monosaccharides are arranged together, by the assemblage of the single polymer chains (Sutherland, 1994), and by the nature of the sugar (Silvi et al., 2013).

The synthesis of EPS in rhizobia is a multi-step process regulated by several genes (named exolexs, exp, or $p s s$ ) at both transcriptional and post-transcriptional levels (Sutherland, 2001; Janczarek and Skorupska, 2011). Further, environmental factors such as concentration of the energy source, nitrogen, phosphate starvation, the $\mathrm{C} / \mathrm{N}$ ratio, and a diverse range of stress conditions (e.g., desiccation, temperature, and ionic strength) affect EPS production. These factors also influence the structure and rheological properties of EPS (Ibarburu et al., 2007; Staudt et al., 2012).

The functional significance of some EPS structures in nodule invasion motivated an investigation of the details of their chemistry (Fraysse et al., 2003; Downie, 2010; Bomfeti et al., 2011). Since there are no studies on the commercial production of gum by rhizobia, they can be considered unexplored sources of microbial polysaccharides, highly promising for industrial applications. Because technological applications and biological properties of EPS are quite dependent on their structural properties, determination of the chemical composition and structure of an EPS is relevant for predicting its potential applications. Therefore, the objective of the present study was to investigate the chemical composition of exopolysaccharides from six different rhizobia species by RP-HPLC, NMR, and FTIR spectroscopies.

\section{MATERIAL AND METHODS}

\section{Bacterial strains and growth conditions}

The strains used throughout this study Mesorhizobium huakuii LMG14107 (isolated from Astragalus sinicus), Mesorhizobium loti LMG6125 (isolated from Lotus corniculatus var. tenuifolium), Mesorhizobium plurifarium LMG11892 (isolated from Acacia senegal), Rhizobium mongolense LMG19141 (isolated from Medicago ruthenica), and Sinorhizobium (= Ensifer) kostiense LMG19227 (isolated from Acacia senegal) - were obtained from the collection of the Laboratorium voor Microbiologie, Universiteit Gent, Belgium. Rhizobium giardini bv. giardini $\mathrm{H} 152^{\mathrm{T}}$ (isolated from Phaseolus vulgaris) was from the collection of the Laboratorie de Microbiologie des Sols, INRA, France.

For routine rhizobia growth, a stock culture was maintained on YMA medium $\left(0.4 \mathrm{~g} \mathrm{~L}^{-1}\right.$ yeast extract, $10 \mathrm{~g} \mathrm{~L}^{-1}$ mannitol, $0.5 \mathrm{~g} \mathrm{~L}^{-1} \mathrm{~K}_{2} \mathrm{HPO}_{4}, 0.2 \mathrm{~g} \mathrm{~L}^{-1} \mathrm{MgSO}_{4}$, and $0.1 \mathrm{~g} \mathrm{~L}^{-1} \mathrm{NaCl}, 9 \mathrm{~g} \mathrm{~L}^{-1}$ agar, $\mathrm{pH}$ 7.0) (Vincent, 1970) and subcultured periodically. To verify the purity of each strain culture, the YMA medium was supplemented with Congo Red $\left(25 \mu \mathrm{g} \mathrm{mL}^{-1}\right)$. The cultures were incubated at $30^{\circ} \mathrm{C}$ for $24 \mathrm{~h}$. 
For comparative analyses of EPS production obtained from the rhizobial strains, the monosaccharide compositions, and the FTIR and NMR analyses of the EPS of the strains, pre-inoculum and batch experiments were performed using Rhizobium defined medium (RDM) $\left(0.23 \mathrm{~g} \mathrm{~L}^{-1} \mathrm{~K}_{2} \mathrm{HPO}_{4}, 0.1 \mathrm{~g} \mathrm{~L}^{-1} \mathrm{MgSO}_{4}\right.$, and $1.1 \mathrm{~g} \mathrm{~L}^{-1} \mathrm{C}_{5} \mathrm{H}_{8} \mathrm{NaO}_{4} \cdot \mathrm{H}_{2} \mathrm{O}, 4 \mathrm{~mL} \mathrm{~L}{ }^{-1}$ glycerol, pH 6.8) (Bishop et al., 1976).

\section{EPS production}

For evaluation of EPS production, the stock culture was used to prepare the inoculum in $125 \mathrm{~mL}$ flasks, containing $50 \mathrm{~mL}$ of the YM. After $24 \mathrm{~h}$, each inoculating strain was cultivated in $125 \mathrm{~mL}$ flasks (20 $\mathrm{mL}$ of medium in each) containing RDM liquid medium on a rotary shaker at $140 \mathrm{rpm}$ for $30 \mathrm{~h}$, at which time a suspension with an optical density at $600 \mathrm{~nm}\left(\mathrm{OD}_{600}\right)$ of 1.0 was obtained. Temperature was maintained at $30{ }^{\circ} \mathrm{C}$. Aliquots of the corresponding cultures were transferred to $1,000 \mathrm{~mL}$ Erlenmeyer flasks containing $500 \mathrm{~mL}$ of RDM liquid medium at a final concentration of $10 \%$ (v/v) and incubated for $144 \mathrm{~h}$ at $160 \mathrm{rpm}$ and $30^{\circ} \mathrm{C}$.

\section{EPS extraction}

Cold $96 \%$ ethanol was added to the supernatant obtained from centrifugation at a $3: 1(\mathrm{v} / \mathrm{v})$ ethanol:supernatant ratio to precipitate the EPS (Breedveld et al., 1990). The mixture was refrigerated at $4{ }^{\circ} \mathrm{C}$ for $24 \mathrm{~h}$. After the refrigeration period, the samples were centrifuged once more $\left(10,000 \mathrm{~g}, 4{ }^{\circ} \mathrm{C}, 30 \mathrm{~min}\right)$ to separate the precipitate from the solvent. The precipitate was washed several times with ethanol, and the ethanol was evaporated. Solvent precipitation also achieved partial purification of the polymer by eliminating the soluble components of the culture media.

The EPS yield was determined gravimetrically after drying using a Hetovac VR-1 lyophilizer until achieving constant weight. The protein contents of the EPS were analyzed by UV spectrophotometry (Nanodrop ND-1000), and then prepared for RP-HPLC, FTIR, and NMR analyses.

\section{Monosaccharide composition}

To assess the monosaccharide composition of the EPS produced by the bacterial strains, each raw EPS preparation was analyzed by RP-HPLC using the 1-phenyl-3-methyl-5-pyrazolone (PMP) monomer chemical identification method described by Fu and O'Neill (1995) and modified by Castellane et al. (2014).

\section{High-performance liquid chromatography (HPLC) analysis of the monosaccharides labeled with PMP}

Analysis of the monosaccharides labeled with PMP was carried out in a reversed phase $\mathrm{C} 18$ column (ODS Shimadzu, $4.6 \mathrm{~mm}$ i.d. $\times 0.15 \mathrm{~m}$ ) on a HPLC system equipped with a UV-Vis (Shimadzu, model
SPD-M10A) detector. The wavelength for detection was $245 \mathrm{~nm}$. A mobile phase system consisted of a gradient program with a combination of solvent $\mathrm{A}$ and solvent $\mathrm{B}$ and a fixed flow rate of $0.5 \mathrm{~mL} \mathrm{~min}^{-1}$. Solvent A was composed of $10 \%$ acetonitrile (J.T. Baker $^{\circledR}$ ) in $0.1 \mathrm{~mol} \mathrm{~L}^{-1}$ ammonium acetate (Fluka) buffer ( $\mathrm{pH}$ 5.5), and solvent B was composed of $25 \%$ acetonitrile in $0.1 \mathrm{~mol} \mathrm{~L}^{-1}$ ammonium acetate buffer (pH 5.5). A gradient of 30 to $100 \%$ buffer B in $55 \mathrm{~min}$, and 100 to $45 \%$ buffer B in $55-65$ min were used for separation. Next, 5 min of initial conditions was applied to re-equilibrate the column for further analyses. The amount of each sample injected into the chromatograph was of $20 \mu \mathrm{L}$.

To check the influence of acid hydrolysis conditions on the elution behaviors of sugars, we subjected solutions of different monosaccharides to similar acid hydrolysis conditions as the EPS, followed by RP-HPLC separation. For quantification of the monomers in the EPS, results were compared with a series of mixed standards containing the following monosaccharides: D-glucose (Glc), D-galactose (Gal), D-galacturonic acid (GalA), L-rhamnose (Rha), D-mannose (Man) (all these sugar were from Sigma Chemical GmbH, Deisenhofen, Germany), and glucuronic acid (GlcA) (Fluka Chemika GmbH, Germany), were derivatized according to the standard protocol. The samples were quantified using Shimadzu CLASS-VP 5 chromatographic software.

\section{FTIR spectroscopic analysis}

Fourier transform infrared (FTIR) is an instrument able to detect the functional groups of purified EPSs. Pellets for infrared analysis were obtained by grinding $1 \mathrm{mg}$ of EPSs with $100 \mathrm{mg}$ of dry potassium bromide, and the mixture was pressed into a $16 \mathrm{~mm}$ diameter mold. The FTIR spectra were recorded on a Paragon 1000, Perkin-Elmer spectrometer $\left(4,000-400 \mathrm{~cm}^{-1}, 2 \mathrm{~cm}^{-1}\right.$ of spectral resolution, and 32 scans). The spectra were baseline corrected from 3,900 to $2,800 \mathrm{~cm}^{-1}$ and from 1,800 to $900 \mathrm{~cm}^{-1}$ and normalized at the peak intensity of $1,050 \mathrm{~cm}^{-1}$ (Osiro et al., 2004, 2011).

\section{NMR spectroscopic analysis}

Solid-state ${ }^{13} \mathrm{C}$ NMR spectra were acquired using a Varian Inova 400 spectrometer at $9.4 \mathrm{~T}$. The solid state spectra were acquired using a Variable Amplitude Cross Polarization Magic Angle Sample Spinning sequence (VACP-MAS). The $1 \mathrm{H} \Pi / 2$ pulse was $\mathrm{pw}=4 \mathrm{~ms}$; contact time, ct $=1 \mathrm{~ms}$; acquistion time, at $=13.8 \mathrm{~ms}$; recycle time, $\mathrm{rt}=3$ $\mathrm{s}$; decoupling bandwidth, $\mathrm{db}=60 \mathrm{KHz}$; spectral width, sw $=40 \mathrm{KHz}$. The samples $(200 \mathrm{mg})$ were packed in a $5 \mathrm{~mm}$ zirconia rotor and spun at magic angle at $9 \mathrm{KHz}$. Chemical shifts are indicated in $\mathrm{ppm}$, and the number of accumulated scans was 10000 , filtered by an exponential function (line broadening factor of $20 \mathrm{~Hz}$ ) (Gadian, 1995). 


\section{Statistical analysis}

All of the determinations reported in this manuscript were performed in triplicate, and the results are presented as mean values. The differences in the mean values of EPS production and monosaccharide composition determinations among the diverse types of rhizobia species were analyzed using the $\mathrm{R}$ software and were subjected to analysis of variance; means were compared by Tukey's test at $5 \%$ probability.

\section{RESULTS AND DISCUSSION}

\section{Isolation of EPS and its characterization}

All EPS produced appeared to be clean and showed a negligible amount of protein $\left(0.09-0.04 \mathrm{mg} \mathrm{mL}^{-1}\right)$. The UV absorption spectra of EPS showed no absorption at 280 and $260 \mathrm{~nm}$, implying that protein and nucleic acid were absent in these polysaccharides.

\section{EPS production}

Rhizobial EPS production was evaluated by weighing the ethyl alcohol precipitate from cultures in a stationary phase, after lyophilization, and expressed as lyophilized weight per liter (Figure 1).

Maximum exopolysaccharide production was $3.10 \mathrm{~g} \mathrm{~L}^{-1}$ for the Mesorhizobium loti LMG6125, followed by Sinorhizobium kostiense LMG19227 (2.72 $\left.\mathrm{g} \mathrm{L}^{-1}\right)$ and Rhizobium mongolense LMG19141 $\left(2.50 \mathrm{~g} \mathrm{~L}^{-1}\right)$ after $144 \mathrm{~h}$ of incubation in RDM medium with glycerol as a $\mathrm{C}$ source. The other rhizobial species, Rhizobium giardini bv. giardini $\mathrm{H} 152^{\mathrm{T}}$, Mesorhizobium huakuii LMG14107, and Mesorhizobium plurifarium LMG11892 have lower values of EPS production, $1.33 \mathrm{~g} \mathrm{~L}^{-1}$, $0.95 \mathrm{~g} \mathrm{~L}^{-1}$, and $0.70 \mathrm{~g} \mathrm{~L}^{-1}$, respectively. Production of EPS by these strains was much higher than that observed for Rhizobium miluonense CC-B-L1, Burkholderia seminalis CC-IDD2w, and Ensifer adhaerens CC-GSB4, which produced 0.212, 0.203 , and $0.198 \mathrm{~g} \mathrm{~L}^{-1}$ of EPS, respectively, in yeast extract mannitol medium (Laus et al., 2004; Huang et al., 2012). Many studies showed that EPS amounts and properties are greatly dependent on microorganisms, their culture conditions, and media composition (Fraysse et al., 2003; Cui and Qiu, 2012; Donot et al., 2012).

\section{Monosaccharide composition of rhizobial exopolysaccharides}

Recently, it was shown that RP-HPLC makes accurate monomer analysis of pure EPS possible. However, in some cases acid hydrolysis of the EPS influenced the elution behaviors of the sugars ( $\mathrm{Fu}$ and O'Neill, 1995). In the

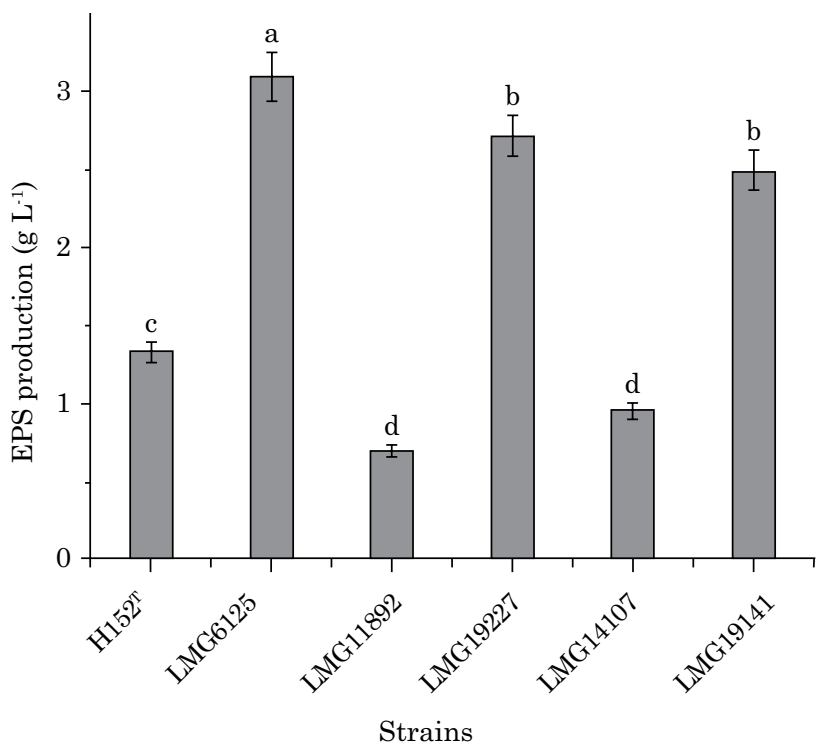

Figure 1. Evaluation of the differences in exopolysaccharide production by Rhizobium giardini bv. giardini $\mathrm{H}_{152}{ }^{\mathrm{T}}$, Mesorhizobium loti LMG6125, Mesorhizobium plurifarium LMG11892, Sinorhizobium (= Ensifer) kostiense LMG19227, Mesorhizobium huakuii LMG14107, and Rhizobium mongolense LMG19141. Bars on columns indicate standard error. Bars labeled with identical letters are not significantly different $(p<0.05)$.

present study, acid hydrolysis conditions did not influence the elution behaviors of sugars (results not shown). After hydrolysis and PMP derivatization, the EPS samples of the six rhizobia strains cultivated in a defined liquid medium were characterized, and the monomer contents were quantified by HPLC (Figure 2). Comparison of the results for monomeric EPS produced by rhizobia strains (Table 1), revealed a significant difference, and biopolymers were identified as heteropolysaccharides.

In the EPS of the six rhizobia species, D-glucose and D-galactose were present in higher amounts than other monosaccharides, representing more than $90 \%$ of the monosaccharide composition (Table 1). D-glucose was found in higher concentration in the EPS produced by the Mesorhizobium huakuii LMG14107, M. plurifarium LMG11892, and Rhizobium giardini bv. giardini $\mathrm{H} 152^{\mathrm{T}}$ strains and had a similar proportion to galactose in the EPS from $R$. mongolense LMG19141, Sinorhizobium kostiense LMG19227, and $M$. loti LMG6125. L-rhamnose present in lower concentration was detected in LMG6125 (3.5 \%) and in LMG19141 (0.5\%), and glucuronic acid was observed in LMG14107 (10.1 \%) and LMG6125 (3.5 $\%)$. L-rhamnose was likewise detected, as well as 


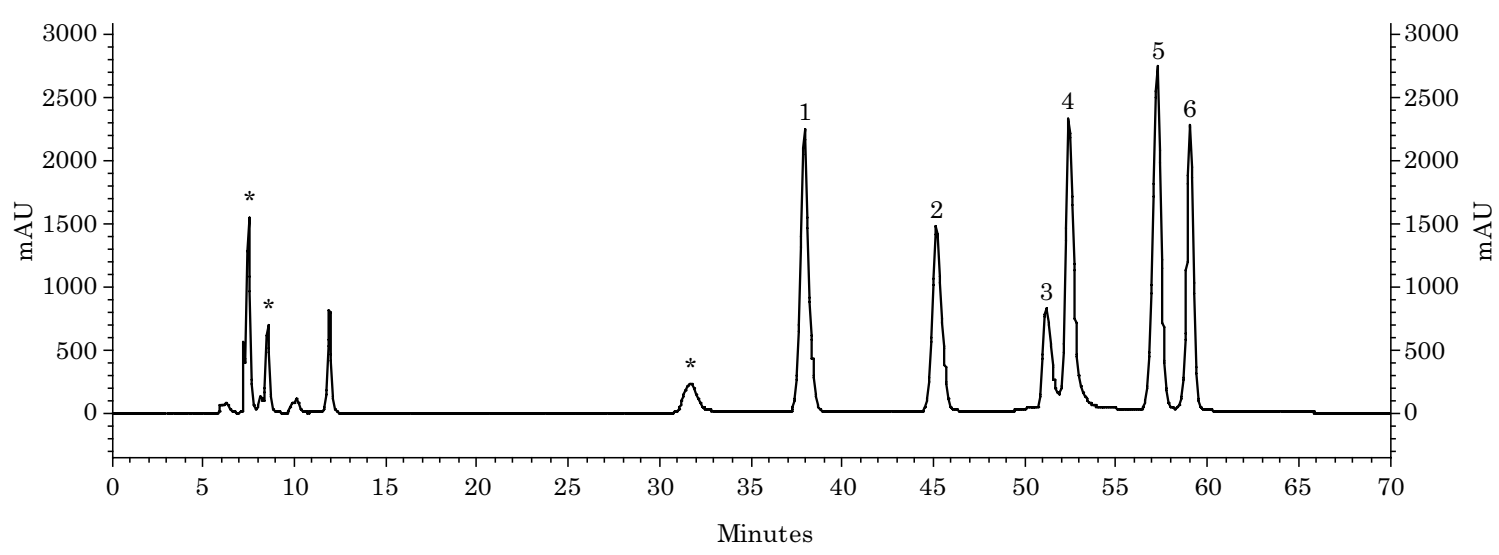

Figure 2. HPLC chromatogram of the working standard solution containing five monosaccharide standards, as recorded at $245 \mathrm{~nm}$. Column: ODS Shimadzu C18 reverse phase $(150 \times 4.6 \mathrm{~mm}, \mathrm{~S}-5 \mathrm{\mu m})$. Elution $(0.5 \mathrm{~mL} \mathrm{~min}-1)$ performed using a gradient program of a combination of solvent $A$ and solvent $B$ containing $10-25 \%$ acetonitrile in $0.1 \mathrm{~mol} \mathrm{~L}^{-1}$ ammonium acetate buffer (pH 5.5) for 70 min. (*) solvents and 1-phenyl-3-methyl-5-pyrazolone residue, (1) mannose, (2) rhamnose, (3) glucuronic acid, (4) galacturonic acid, (5) glucose, and (6) galactose.

Table 1. Monomer compositions of exopolysaccharides produced by different rhizobia species cultured in Rhizobium defined medium (RDM) for 6 days at $30^{\circ} \mathrm{C}$

\begin{tabular}{|c|c|c|c|c|}
\hline \multirow{2}{*}{ Rhizobia specie } & \multicolumn{4}{|c|}{ Monomer compositions $(\mathrm{mol} \%)^{(1)}$} \\
\hline & Rhamnose & Glucuronic acid & Galacturonic acid & Galactose \\
\hline Rhizobium giardini bv.giardini $\mathrm{H} 152^{\mathrm{T}}$ & $\operatorname{tr}$ & $\operatorname{tr}$ & $80.0 \mathrm{a}$ & $20.0 \mathrm{c}$ \\
\hline Mesorhizobium loti LMG 6125 & $3.5 \mathrm{a}$ & $3.5 \mathrm{a}$ & $51.5 \mathrm{~b}$ & $41.5 \mathrm{~b}$ \\
\hline Mesorhizobium plurifarium LMG 11892 & $\operatorname{tr}$ & $\operatorname{tr}$ & $63.0 \mathrm{ab}$ & $37.0 \mathrm{~b}$ \\
\hline Sinorhizobium kostiense LMG 19227 & $\operatorname{tr}$ & $0.7 \mathrm{c}$ & $42.7 \mathrm{bc}$ & $56.6 \mathrm{a}$ \\
\hline Mesorhizobium huakuii LMG14107 & $\operatorname{tr}$ & $10.1 \mathrm{a}$ & $66.1 \mathrm{ab}$ & $23.8 \mathrm{c}$ \\
\hline Rhizobium mongolense LMG 19141 & $0.5 \mathrm{~b}$ & $\operatorname{tr}$ & $50.0 \mathrm{~b}$ & $49.5 \mathrm{ab}$ \\
\hline
\end{tabular}

(1) tr: trace mean $<1 \%$. Means in the same column followed by different letters are significantly different $(\mathrm{p}<0.05)$.

uronic acids, which accounts for the acidic nature of the polymer. The presence of ketals or uronic acids results in linear polyanionic macromolecules (Sutherland, 2001).

A large diversity in EPS chemical structure can be found within the Rhizobium genus, considering the sugar composition and linkage in the single subunit, the repeating unit size, and the degree of polymerization, as well as non-carbohydrate decoration (Skorupska et al., 2006). The chemical compositions of EPS produced by species of rhizobia have been described; for example, EPS with characteristics of gel produced by Rhizobium tropici and Mesorhizobium sp are acidic heteropolysaccharides composed mainly of Glc and Gal in a molar ratio of $4: 1$ and $5: 1$, respectively, with traces of mannose (Monteiro et al., 2012); and the EPS produced by Rhizobium sullae strain KYGT207 are mainly constituted by neutral sugars (D-glucose,
D-galactose, L-fucose, D-mannose, and sometimes L-rhamnose) (Kaci et al., 2005; Gharzouli et al., 2013). The presence of fucose and, more specifically, the importance of its ratio reported here indicate that we are in the presence of a novel type of rhizobial EPS (Gharzouli et al., 2013).

However, heteropolysaccharide is produced in great variety in regard to chemical composition, monomer ratio, and the molecular structure of the repeating unit, but also regarding the molecular mass of the polymer (Sutherland, 2001; Donot et al., 2012).

\section{${ }^{13}$ C NMR spectroscopic characterization of EPS}

Spectroscopy, including NMR (Lattner et al., 2003), FTIR (Sheng et al., 2006), X ray photoelectron spectroscopy (XPS) (Ortega-Morales et al., 2007), and 3-dimensional excitation- emission matrix fluorescence spectroscopy (3D-EEM) (Sheng et al., 
2006), can be used to elucidate functional groups and element compositions and to assess most of the linkages in EPS or microbial aggregates. NMR analysis allowed us to determine the functional groups of extracellular polysaccharide.

The ${ }^{13} \mathrm{C}$ NMR spectrum can be divided into different regions. Based on chemical shifts in ${ }^{13} \mathrm{C}$ NMR (Figure 3), signals at 25 and $175.5 \mathrm{ppm}$ were detected, which are characteristic of the methyl carbon and carboxyl $\mathrm{C}$ of the pyruvic acid moiety, respectively (Zhao et al., 2010). The methyl signal of acetate at $21 \mathrm{ppm}$, for its part, is observed only in the spectra of LMG6125, LMG11892, LMG14107, and LMG19141 EPS (Figure 3). The methyl signal of pyruvate at $25 \mathrm{ppm}$ is observed in the spectra of $\mathrm{H} 152^{\mathrm{T}}$, LMG11892, and LMG19141 EPS (Figures 3a, 3c, 3f). The methylene signal of succinate at $31 \mathrm{ppm}$ is observed in the spectra of H152 ${ }^{\mathrm{T}}$, LMG19227 (very weak), and LMG19141 (Figures 3a, 3d, 3f).

The ${ }^{13} \mathrm{C}$ NMR spectrum of EPS exhibited one signal in the anomeric region at $104.1 \mathrm{ppm}$ (Figure 2), attributed to the $\beta$-anomeric carbon of the glucopyranosyl unit reducing end (Corradi da

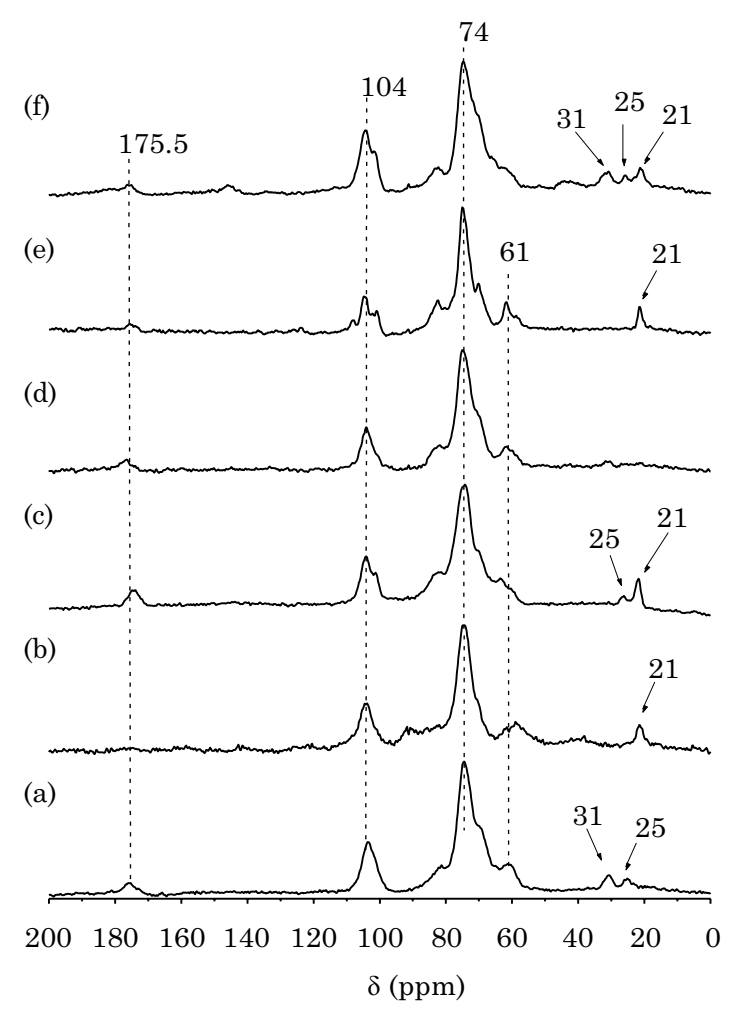

Figure $3 .{ }^{13} \mathrm{CNMR}$ spectrum of the exopolysaccharides produced by: (a) Rhizobium giardini bv. giardini $\mathrm{H152}^{\mathrm{T}}$, (b) Mesorhizobium loti LMG6125, (c) Mesorhizobium plurifarium LMG11892, (d) Sinorhizobium (= Ensifer) kostiense LMG19227, (e) Mesorhizobium huakuii LMG14107, and (f) Rhizobium mongolense LMG19141.
Silva et al., 2005) and pyruvate ketal carbons. These data are in agreement with the results reported by Osiro et al. (2011), where the ${ }^{13} \mathrm{C}$ signals for anomeric carbons of the glucose in xanthan and for $\mathrm{C} 2$ of the pyruvic acid ketal group were at $105 \mathrm{ppm}$. Dahecha et al. (2013) reported on the other five main resonance shifts at 59.7(C-1), 63.3(C-6), 75.1(C-4), $76.1(\mathrm{C}-3)$, and $80.2 \mathrm{ppm}(\mathrm{C}-5)$ relating to quaternary anomeric carbons detected in the ${ }^{13} \mathrm{C}$ NMR spectrum for levan.

The ${ }^{13} \mathrm{C}$ NMR spectra of EPS (Figure 3) also shows signals near $176 \mathrm{ppm}$ are attributed to the carboxyl carbons of acetate, pyruvate, and succinate esters and pyruvic, succinic, and glucuronic acids. The intensities of the carbonyl signals at $176 \mathrm{ppm}$ decline in the following order: LMG11892 $>\mathrm{H} 152^{\mathrm{T}}>$ LMG19227 = LMG19141>LMG14107. The spectrum of LMG6125 EPS does not contain a detectable carbonyl signal, but acetate is present, as confirmed by the signal at $21 \mathrm{ppm}$.

These EPS could be classified into several groups based on ester type, as determined from the ${ }^{13} \mathrm{C}$ NMR spectra (Figure 3 ). The first group of EPS (two strains: Mesorhizobium loti LMG6125 and M. huakuii LMG14107) contained acetate only. A second group of EPS (Sinorhizobium kostiense LMG19227) consisted of succinate only. The EPS of strain $M$. plurifarium LMG11892 contained acetate and pyruvate (group III), whereas the strain Rhizobium giardini bv. giardini $\mathrm{H} 152^{\mathrm{T}}$ produced EPS which contained pyruvate and succinate (group IV). The EPS belonging to group V (Rhizobium mongolense LMG19141) contained all three esters.

\section{FTIR spectroscopy analysis of EPS}

Fourier transform infrared (FTIR) is an effective analytical instrument for detecting functional groups and characterizing covalent bonding information. The technique is based on the fact that bonds and groups of bonds vibrate at characteristic frequencies. The FTIR spectrum of rhizobial EPS was analyzed and absorption bands were assigned to reveal the typical polymeric structure of the carbohydrate (Figure 4). In comparison with the IR spectra of polysaccharides documented in the literature, characteristic absorption bands in the region of $3,400 \mathrm{~cm}^{-1}$ were considered as the results of the hydroxyl stretching vibration of the polysaccharide. This is the characteristic absorption band of the carbohydrate ring and is responsible for the water solubility of EPS (Karbowiak et al., 2007). The bands in the region from $2,960 \mathrm{~cm}^{-1}$ to $2,850 \mathrm{~cm}^{-1}$ represented the $\mathrm{C}-\mathrm{H}$ stretching vibration of the methyl and methylene groups $\left(-\mathrm{CH}_{2}-\right)$, usually present in hexoses, like glucose or galactose, or deoxyhexose, like rhamnose.

We assign the bands at $1,735 \mathrm{~cm}^{-1}$ to the carbonyl stretch $\mathrm{C}=\mathrm{O}$ of esters. This stretching absorption 

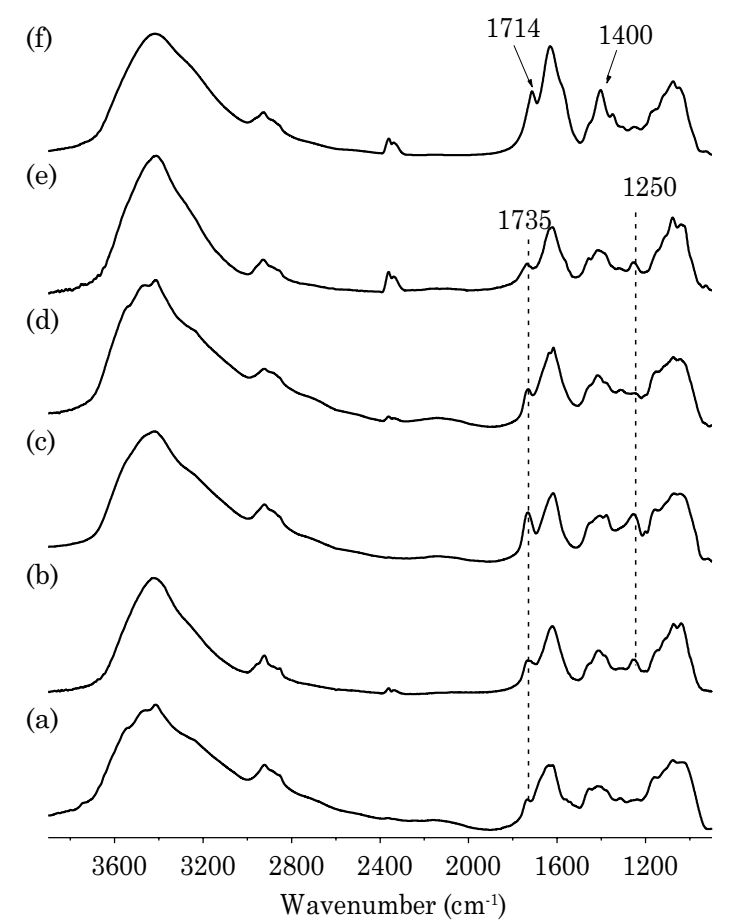

Figure 4. Infrared spectrum of the exopolysaccharides produced by (a) Rhizobium giardini bv.giardini $\mathrm{H152}^{\mathrm{T}}$, (b) Mesorhizobium loti LMG6125, (c) Mesorhizobium plurifarium LMG11892, (d) Sinorhizobium (= Ensifer) kostiense LMG19227, (e) Mesorhizobium huakuii LMG14107, and (f) Rhizobium mongolense LMG19141.

produced stronger peaks in the FTIR spectrum of the EPS (Figure 4c) extracted from the strain LMG11892, suggesting that this strain contains the highest concentrations of acetate and pyruvate, which was in accordance with the results of ${ }^{13} \mathrm{C}$ NMR (Figure 4). The FTIR spectrum of the EPS produced by the LMG19141 shows a signal at $1,714 \mathrm{~cm}^{-1}$, which corresponds to carboxylic acids and oscillation bands of the carboxylate ion at approximately 1,633 and $1,400 \mathrm{~cm}^{-1}$.

The signal at $1,615 \mathrm{~cm}^{-1}$ can be attributed to $-\mathrm{OH}$ angular deformation (Figure 4). For the strain of $R$. giardini bv. giardini $\mathrm{H} 152^{\mathrm{T}}$, the signal at $1,633 \mathrm{~cm}^{-1}$ can be attributed to $-\mathrm{OH}$ angular deformation. These signals $\left(1,615\right.$ and $\left.1,633 \mathrm{~cm}^{-1}\right)$ are more related to the $-\mathrm{OH}$ monosaccharide backbone than to the carboxylate ions. The rhizobial EPS FTIR spectrum (Figure 4a) also shows weak signals at $1,400 \mathrm{~cm}^{-1}$ and at $1,250 \mathrm{~cm}^{-1}$ due to carboxylate asymmetric stretching and stretching of the $\mathrm{C}=\mathrm{O}$ group, respectively. However, the signal at $1,400 \mathrm{~cm}^{-1}$ is not observed in other exopolysaccharides (Figures $4 \mathrm{~b}$, $4 \mathrm{c}, 4 \mathrm{~d}, 4 \mathrm{e}, 4 \mathrm{f})$. All the vibrational peaks were similar to the peaks obtained for a standard exopolysaccharide (xanthan), confirming its nature as a polysaccharide (Figure 4 ).
The wave number region from 1,200 to $800 \mathrm{~cm}^{-1}$ is the fingerprint region and can be used to characterize different polysaccharides (Copikova et al., 2006). The absorption bands in the $983-1,200 \mathrm{~cm}^{-1}$ region suggested the presence of sugar monomers, such as glucose and galactose, in the Rhizobial EPS. In the anomeric region, the absorption band around $796 \mathrm{~cm}^{-1}$ that revealed the possible presence of alpha glycosidic linkages is not observed. Most documented polysaccharides from rhizobia are linked in alpha or beta conformations through several possible glycosidic linkages (Chouly et al., 1995; Fraysse et al., 2003; Bomfeti et al., 2011). However, the difference in chemical composition, type of glycosidic linkage, and degree of polysaccharide branching influence the secondary and tertiary structures of the single chains and their macromolecular assembly, determining the physical properties of the polysaccharide, which are related to the polysaccharides structural or physiological functions (Sutherland, 2001).

The FTIR spectra of the polymer showed the presence of carboxyl and hydroxyl groups, which may serve as binding sites for divalent cations. Such complexes of metal ions with neutral carbohydrates are well documented by Angyal (1989) and others. The presence of the hydroxyl group in B-position can contribute to the stability of such complexes. Alduronate ions form much stronger complexes with cations than neutral sugars. Kaplan et al. (1987) reported that the sulfate ester group plays a minor role in metal chelation as compared to uronic acid. In addition, the presence of acidic sugars in the EPS may be important, considering the heavy metal-binding properties of this polymer.

A wide variety of compounds have been reported from rhizobia. However, unlike those from other species, the EPS composition reported here for rhizobia has not previously been reported. One research group only noted the appearance of colonies characterized by high gum production in a solid medium, and the precipitation of EPS from strains of $M$. plurifarium BR3804 and R. tropici CIAT899 ${ }^{\mathrm{T}}$, which are recommended by MAPA (Ministério da Agricultura, Pecuária e Abastecimento) of Brazil as inoculants for the species Chamaecrista ensiformis and Phaseolus vulgaris, respectively, demonstrating the high potential of these strains for production of these biopolymers (Bomfeti et al., 2011).

\section{CONCLUSIONS}

The combination of the three analytical techniques makes it possible to determine rhizobial exopolysaccharides are species-specific heteropolysaccharide polymers composed of common sugars that are substituted by non-carbohydrate moieties. 
Rhizobial EPS can be classified into five groups, according to the example based on ester type, as determined from the ${ }^{13} \mathrm{C} \mathrm{NMR}$ spectra.

The genus Rhizobium can be included among the potential sources of promising biopolymers because none of the a and B-rhizobia have yet been shown to be pathogenic, and knowledge of EPS composition now facilitates further investigations relating polysaccharide structure and dynamics to rheological properties.

\section{ACKNOWLEDGMENTS}

We are grateful to Denise Osiro and Luis Alberto Conalgo from the Embrapa Instrumentação Agropecuária, Empresa Brasileira de Pesquisa Agropecuária, São Carlos, Brazil, for their help in FTIR and NMR spectroscopy analysis. We thank João Carlos Campanharo for excellent scientific and technical support and also acknowledge financial support from FAPESP - Fundação de Amparo a Pesquisa do Estado de São Paulo (FAPESP: 2001/05720-4 and 2010/11957-6).

\section{REFERENCES}

Angyal SJ. Complexes of metal cations with carbohydrates in solution. Adv Carbohidr Chem Biochem. 1989;47:1-43.

Berrada H, Fikri-Benbrahim K. Taxonomy of the rhizobia: current perspectives. British Microbiol. Res J. 2014;4:616-39.

Bishop PE, Guevara JG, Engelke JA, Evans, J.H. Relation between glutamine synthetase and nitrogenase activities in the symbiotic association between Rhizobium japonicum and Glycine max. Plant Physiol. 1976;57:542-6.

Bomfeti CA, Florentino AF, Guimarães AP, Cardoso PG, Guerreiro MC, Moreira FMS. Exopolysaccharides produced by the symbiotic nitrogen-fixing bacteria of leguminosae. $\mathrm{R}$ Bras $\mathrm{Ci}$ Solo. 2011;35:657-71.

Breedveld MW, Zevenhuizen LPTM, Zehnder AJB. Osmotically induced oligo- and polysaccharide synthesis by Rhizobium meliloti SU-47. J Gen Appl Microbiol. 1990;136:2511-9.

Carareto LM, Marcondes JA, Varani AM, Lemos EGM. Rhizobiaceae Family. In: Rosenberg E, Delong EF, Thompson F, Lory S, Stackebrandt E, editors. The Prokaryotes. 4th.ed. Berlin/Heidelberg/New York: Springer-Verlag; 2014. p.419-37.

Castellane TCL, Lemos EGM. Composição de exopolissacarídeos produzidos por estirpes de rizóbios cultivados em diferentes fontes de carbono. Pesq Agropec Bras. 2007;42:1503-6.

Castellane TCL, Lemos MVF, Lemos EGM. Evaluation of the biotechnological potential of Rhizobium tropici strains for exopolysaccharide production. Carbohydr Polym. 2014;111:191-7.

Castellane TCL, Persona MR, Campanharo JC, Lemos EGM. Production of exopolysaccharide from rhizobia with potential biotechnological and bioremediation applications. Inter J Biol Macromol. 2015;74:515-22.

Choi JM, Kim H, Cho E, Choi Y, Lee IS, Jung S. Solubilization of haloperidol by acyclic succinoglycan oligosaccharides. Carbohydr Polym. 2012;89:564-70.

Chouly C, Colquhoun IJ, Jodelet A, York G, Walker GC. NMR studies of succinoglycan repeating-unit octasaccharides from Rhizobium meliloti and Agrobacterium radiobacter. Int J Biol Macromol. 1995;17:357-63.

Copikova J, Barros AS, Smidova I, Cerna M, Teixeira DH, Delgadillo I, Syystya A, Coimbra MA. Influence of hydration of food additive polysaccharides on FT-IR spectra distinction. Carbohydr Polym. 2006;63:355-9.

Corradi da Silva ML, Izeli NL, Martinez PF, Silva IR, Constantino CJ, Cardoso MS, Barbosa AM, Dekker RF, Silva GV. Purification and structural characterisation of $(1 \rightarrow 3 ; 1 \rightarrow 6)$-B-D-glucans (botryosphaerans) from Botryosphaeria rhodina grown on sucrose and fructose as carbon sources: a comparative study. Carbohydr Polym. 2005;61:10-7.

Cui JD, Qiu JQ. Production of extracellular water-insoluble polysaccharide from Pseudomonas sp. J Agric Food Chem. 2012;60:4865-71.

Dahecha I, Fakhfakhb J, Damakb M, Belghithc H, Mejdouba $\mathrm{H}$, Belghitha KS. Structural determination and NMR characterization of a bacterial exopolysaccharide. Inter J Biol Macromol. 2013;59:417-22.

Donot F, Fontana A, Baccou JC, Schorr-Galindo S. Microbial exopolysaccharides: Main examples of synthesis, excretion, genetics and extraction. Carbohydr Polym. 2012;87:951-62.

Downie JA. The roles of extracellular proteins, polysaccharides and signals in the interactions of rhizobia with legume roots. FEMS Microbiol Rev. 2010;34:150-70.

Fraysse N, Couderc F, Poinsot V. Surface polysaccharide involvement in establishing the rhizobium-legume symbiosis. Eur J Biochem. 2003;270:1365-80.

Freitas F, Alves VD, Pais J, Costa N, Oliveira C, Mafra L, Hiliou L, Oliveira R, Reis MA. Fucose-containing exopolysacharide produced by the newly isolated Enterobacter strain A47 DSM 23139. Carbohydr Polym. 2011;1:159-65.

Fu D, O'neill RA. Monossaccharide composition analysis of oligosaccharides and glycoproteins by high performance liquid chromatography. Anal Biochem. 1995;227:377-84.

Gadian DG. NMR and its applications to living systems. 2nd ed. Oxford: Oxford University Press; 1995.

Gharzouli R, Carpéné MA, Couderc F, Benguedouar A, Poinsot V. Relevance of fucose-rich extracellular polysaccharides produced by rhizobium sullae strains nodulating Hedysarum coronarium L. legumes. Appl Environ Microbiol. 2013;79:1764-76.

Huang KH, Chen BY, Shen FT, Young CC. Optimization of exopolysaccharide production and diesel oil emulsifying properties in root nodulating bacteria. World J Microbiol Biotechnol. 2012;28:1367-73.

Ibarburu I, Soria-Díaz ME, Rodríguez-Carvajal MA, Velasco SE, Tejero-Mateo P, Gil-Serrano AM, Irastorza A, Dueñas MT. Growth and exopolysaccharide (EPS) production by Oenococcus oeni I4 and structural characterization of their EPSs. J Appl Microbiol. 2007;103:477-86. 
Janczarek M, Skorupska A. Modulation of rosR expression and exopolysaccharide production in Rhizobium leguminosarum bv. trifolii by phosphate and clover root exudates. Inter J Molec Sci. 2011;12:4132-55.

Kaci Y, Heyraud A, Barakat M, Heulin T. Isolation and identification of an EPS producing Rhizobium strain from arid soil (Algeria): characterization of its EPS and the effect of inoculation on wheat rhizosphere soil structure. Res Microbiol. 2005;156:522-31.

Kaplan D, Christianen D, Arad SM. Chelating properties of extracellular polysaccharides from Chlorella spp. Appl Environ Microbiol. 1987;53:2953-6.

Karbowiak T, Ferret E, Debeaufort F, Voilley A, Cayot A. Investigation of water transfer across thin layer biopolymer films by infrared spectroscopy. J Membr Sci. 2007;370:82-90.

Lattner D, Flemming HC, Mayer C. ${ }^{13} \mathrm{C}$-NMR study of the interaction of bacterial alginate with bivalent cations. Inter $\mathrm{J}$ Biol Macromol. 2003;31:81-8.

Laus MC, Logman TJ, van Brussel AA, Carlson RW, Azadi $\mathrm{P}$, Gao MY, Kijne JW. Involvement of exo5 in production of surface polysaccharides in Rhizobium leguminosarum and its role in nodulation of Vicia sativa subsp. nigra. J Bacteriol. 2004;186:6617-25.

Marcondes JA, Carareto LM, Varani AM, Lemos EGM. Bradyrhizobiaceae Family. In: Rosenberg E, Delong EF, Thompson F, Lory S, Stackebrandt E, editors. The Prokaryotes. 4th.ed. Berlin/Heidelberg/New York: Springer-Verlag; 2014. p.135-54.

Monteiro NK, Aranda-Selverio G, Exposti DTD, Silva M, Lemos EGM, Campanharo JC, Silveira JLMS. Caracterização química dos géis produzidos pelas bactérias diazotróficas Rhizobium tropici e Mesorhizobium sp. Quim Nova. 2012;35:705-8.

Ortega-Morales BO, Santiago-Garcia JL, Chan-Bacab MJ, Moppert X, Miranda-Tello E, Faradeau ML, Carrero JC, Bartolo-Pérez P, Valadéz-González A, Guezennec J. Characterization of extracellular polymers synthesized by tropical intertidal biofilm bacteria. J Appl Microbiol. 2007;102:254-64.
Osiro D, Colnago LA, Otoboni AMMB, Lemos EGM, Souza AA, Coletta Filho HD, Machado MA. A kinetic model for Xylella fastidiosa adhesion, biofilm formation, and virulence. FEMS Microbiol Lett. 2004;236:313-8.

Osiro D, Franco RWA, Colnago LA. Spectroscopic characterization of the exopolysaccharide of Xanthomonas axonopodis pv. citri in $\mathrm{Cu}^{2+}$ resistance mechanism. J Braz Chem Soc. 2011;22:1339-47.

Sheng GP, Yu HQ, Wang CM. FTIR-spectral analysis of two photosynthetic hydrogen producing strains and their extracellular polymeric substances. Appl Microbiol Biotechnol. 2006;73:204-10.

Silvi S, Barghini P, Aquilanti A, Juarez-Jimenez B, Fenice M. Physiologic and metabolic characterization of a new marine isolate (BM39) of Pantoea sp. producing high levels of exopolysaccharide. Microbiol Cell Fact. 2013;12:10-21.

Singh RS, Saini GK. Biosynthesis of pullulan and its applications in food and pharmaceutical industry. In: Satyanarayana T, Johri BN, Prakash A, editors. Microorganisms in sustainable agriculture and biotechnology. New York: Springer-Verlag; 2012. p.509-53.

Skorupska A, Janczarek M, Marczak M, Mazur A, Król J. Rhizobial exopolysaccharides: Genetic control and symbiotic functions. Microbiol Cell Fact. 2006;5:1-19.

Staudt AK, Wolfe LG, Shrout JD. Variations in exopolysaccharide production by Rhizobium tropici. Arch Microbiol. 2012;194:197-206.

Sutherland IW. Structure-function relationship in microbial exopolysaccharides. Biotechnol Adv. 1994;12:393-448.

Sutherland IW. The biofilm matrix-an immobilized but dynamic microbial environment. Trends Microbiol. 2001;9:222-7.

Vincent JM. A Manual for the practical study of root-nodule bacteria, IBP handbook. $15^{\text {th }}$.ed. Oxford: Blackwell Scientific; 1970.

Whitfield C. Bacterial extracellular polysaccharides. Can J Microbiol. 1988;34:415-20.

Zhao L, Dong Y, Chen G, Hu Q. Extraction, purification, characterization and antitumor activity of polysaccharides from Ganoderma lucidum. Carbohyd Polym. 2010;80:783-9. 